Vol. 1 No. 2, January 2022

e- ISSN 2809 - 1922 , p-ISSN 2809 - 1914

Available online at:

Journal of Applied Linguistics

https://journal.eltaorganization.org/index.php/joal/index

\title{
The Correlation between Emotional Intelligence and English Achievement of the 2015/2016 Fifth Semester Students of English Literature Department of UIN Alauddin Makassar
}

\author{
Aswinda Darwis \\ STAI DDI Pinrang \\ aswindadarwis77@gmail.com
}

\begin{abstract}
This research is intended to find out whether or not there is a significant correlation between emotional intelligence and English achievement of the fifth semester students of English literature department of UIN Alauddin Makassar and to explore how the high, moderate, and low achiever students learn and engage in English. In conducting the research, the researcher used mixed method in which both quantitative and qualitative approach were applied. Emotional intelligence questionnaire by Goleman was administered to 33 students and their scores were correlated to their English achievement (GPA) by using Pearson correlation coefficient. Observation and interview were carried out to get more detailed information about how the high, moderate, and low achiever students learn and engage in English. The result revealed that there was significant correlation between emotional intelligence and English achievement of both the high and moderate achiever of the fifth semester students of English literature department of UIN Alauddin Makassar. While for the low achievers there was not significant correlation. In addition, the high, moderate, and low achiever students were different in learning and engaging in English.
\end{abstract}

Key Words : Correlational Research, Emotional Intelligence, English Achievement

\section{Introduction}

Students are different one another in how successful they are in learning English as their second language. Some students learn English more easily while others learn with more difficultly. Some get high, moderate, while others get low achievement. Many people assume that it happens because they are different in cognitive intelligence (IQ). While in fact, it is often found a student who has high IQ however he does not meet with success and in another case, a student with a moderate level of IQ but good at emotional aspect, he can get better result of his study. He can succeed far beyond anyone's expectations.

The college years can be an emotional time for the students. How they handle their emotions in learning may be one indicator of their potential success in college. Some researches in Emotional Intelligence suggest that students who are able to recognize and manage their moods, feelings, and attitudes well may do better academically. Supported by Goleman (1995), he stated that success depends on several intelligences and the control of emotions. IQ only contributes $20 \%$, and the rest goes for emotional and social intelligence, and luck. 
Considering emotional Intelligence as one of the important factors in students' English achievement, the writer was inteded to find out whether or not there is significan correlation between emotional intelligence and English achievement of the fifth semester students of English literature department of UIN Alauddin Makassar and to explore how the high, moderate, and low achiever English students learn and enagage in English.

Emotional intelligence (EI) is a relatively new concept which is intended to complement the traditional view of intelligence by emphasizing the emotional, personal, and social contributions to intelligent behavior (Gardner: 1983).

Goleman (1995) defines emotional intelligences as the capacity for recognizing both our own and others' feeling, for motivating ourselves, and for managing emotions well not only ourselves but also our relationships. According to this definition, emotional intelligence is a foundation for the development of a large number of competencies that can help learners to learn and perform more effectively.

Goleman (1995: 34) presented five skills involved in emotional intelligence: 1. Having awareness of one's emotions (self-awareness), 2. Managing emotions (self- regulation), 3. Motivating oneself, 4. Recognizing others' emotion (empathizing), 5. Relating or socializing well with others in groups (handling relationship/ social skill). He explained that those five skills can be learned as any other subjects. The skills can be learned through modeling, direct instruction, or coaching. By those ways, the lecturers can help students to learn how they should control their own positive and negative feelings, handle difficulties and frustrations calmly without giving up, channel their motivation to learn in positive ways, and relate to others in a supportive manner.

High EQ students are more likely to be better learners, more optimistic, creative, confident as well as flexible, happier, successful at solving problems, able to cope with stress with a higher self esteem and fewer behavior problems, and also able to handle emotions much better (Abraham, 1999; Cooper, 1997; Hein, 1996)

\section{Method}

This research used mixed method in which both quantitative and qualitative approaches were applied to collect and analyze the data. The subjects of the study were 33 students of the 2015/2016 fifth semester of English literature department of UIN Alauddin Makassar. The students were randomly selected from among 110 students of 3 classes. There were high achiever (whose GPA ranged from 3.51 to 4.00), moderate achiever (2.76-3.50), and low achiever (2.00- 2.75).

In this research, the researcher used four kinds of instrument, namely: questionnaire, documentation, observation, and interview. The Emotional Intelligence questionnaires by Daniel Goleman were administered to the 33 English students. The students' emotional intelligence scores were correlated with their English achievement (GPA) taken from college records. Observation and interview were carried out to get the qualitative data about how the high, moderate, and low achiever students learn and engage in English. Data analysis was in two stages. For the quantitative analysis, the quantitative data taken from students' score on EI questionnaire and from their GPA was analyzed by using SPSS 16.0 for windows to find out whether or not there was a significant correlation between students' emotional intelligence and their English achievement. Whiile for the qualitative analysis, the data analysis began from the initial interaction with participants and continued throughout the entire study. In this research, the researcher analyzed how the high, moderate, and low achiever students learn and engage in English related to their emotional intelligence. Experiences or stories in learning English obtained from observation and interview were analyzed to produce a clear and detailed description about how the students' emotional intelligence in learning English. The analysis was based on Goleman's components of Emotional Intelligence (self- awareness, self regulation, motivation, empathy, and social skill). Data analysis 
in qualitative research is continuous and iterative process. It deals with data reduction, data display, and conclusion.

\section{Findings and Discussion}

The Correlation between Emotional Intelligence and English Achievement of the 2015/2016 Fifth Semester Students (high, moderate, and low achiever) of English Literature Department of UIN Alauddin Makassar.

Table 1. High Achiever Students

\begin{tabular}{cccc}
\hline No & Students & EI Score & GPA \\
\hline 1 & SJ & 194 & 3.64 \\
2 & MT & 178 & 3.64 \\
3 & DN & 202 & 4.00 \\
4 & AG & 196 & 3.78 \\
5 & AF & 186 & 3.64 \\
6 & NH & 185 & 3.73 \\
7 & AP & 190 & 3.64 \\
8 & NS & 232 & 4.00 \\
9 & AN & 180 & 3.67 \\
10 & OC & 170 & 4.00 \\
11 & CA & 172 & 3.55 \\
12 & DS & 194 & 3.73 \\
13 & DH & 183 & 3.64 \\
14 & IP & 169 & 3.64 \\
15 & WW & 188 & 3.64 \\
16 & KR & 183 & 3.78 \\
17 & MR & 215 & 3.82 \\
18 & AD & 178 & 3.82 \\
19 & DL & 218 & 3.82 \\
20 & SD & 183 & 3.73 \\
21 & FB & 196 & 3.91 \\
22 & HS & 190 & 3.67 \\
\hline
\end{tabular}

Based on table 1 above, it showed that referring to the students' GPA, there were 22 students categorized as high achiever students. The highest score of the student's GPA was 4.00 and the lowest score was 3.55. while for the EI score, the highest was 232 and the lowest was 169.

To answer the first research question about whether or not there is a significant correlation between emotional intelligence and English achievement of the fifth semester students of English literature department, the researcher applied Pearson Correlation Coefficient to each group of students category: high, moderate, and low achiever. It was intended to compare the probability value ( $\mathrm{p}$ ) and $\alpha$ value $=0.05 / 0.01$. If $\mathrm{p}<\alpha$, it indicated that there is a significant correlation between the two variables) while if $p>\alpha$, it means that there is no significant correlation between the two variables. 
Table 2. Pearson Correlation Coefficient between Emotional Intelligence and English Achievement of High Achiever Students

\begin{tabular}{llrr}
\hline & & EMOTIONAL & GRADE POINT \\
& & INTELLIGENCE & AVERAGE \\
\hline EMOTIONAL & Pearson Correlation & 1 & $.492^{*}$ \\
INTELLIGENC & Sig. (2-tailed) & & .020 \\
$\mathrm{E}$ & $\mathrm{N}$ & 22 & 22 \\
\hline GRADE POINT & Pearson Correlation & $.492^{*}$ & 1 \\
AVERAGE & Sig. (2-tailed) & .020 & \\
& $\mathrm{~N}$ & 22 & 22 \\
\hline
\end{tabular}

*. Correlation is significant at the 0.05 level (2-tailed).

Based on the table correlation coefficient of high achiever students above, it showed that the significant correlation between emotional intelligence and English achievement of the high achiever of the 2015/2016 fifth semester students of English literature department of UIN Alauddin Makassar was 0.020. Therefore, it indicated that there was significant correlation between the two variables because the correlation was significant at the 0.05 level. In another word, Emotional intelligence had a contribution to the students English achievement. Most of the students with a good emotional intelligence were also good at learning and engaging in English.

Table 3. Moderate Achiever Students

\begin{tabular}{cccc}
\hline No & Students & EI Score & GPA \\
\hline 1 & IS & 176 & 3.44 \\
2 & RH & 172 & 3.45 \\
3 & SR & 174 & 3.45 \\
4 & IR & 160 & 3.45 \\
5 & RD & 198 & 3.36 \\
6 & NR & 161 & 3.45 \\
7 & NF & 222 & 3.36 \\
8 & HN & 190 & 3.36 \\
9 & NM & 198 & 3.36 \\
\hline
\end{tabular}

Based on the table 3 above, there were 9 students categorized as moderate achiever. The highest score of the student's GPA was 3.45 and the lowest was 3.36. while for Emotional Intelligence score, the highest was 222 and the lowest was 160.

Table 4. Pearson Correlation Coefficient between Emotional Intelligence and English Achievement of Moderate Achiever Students

\begin{tabular}{llcc}
\hline & & EMOTIONAL & GRADE POINT \\
& & INTELLIGENCE & AVERAGE \\
\hline EMOTIONAL & Pearson Correlation & 1 & $-.877^{* *}$ \\
INTELLIGENCE & Sig. (2-tailed) & & .002 \\
& $\mathrm{~N}$ & 9 & 9 \\
\hline
\end{tabular}

Published by English Lecturers and Teachers Association (ELTA)

Copyright (C) 2022, authors 


\begin{tabular}{llcc}
\hline GRADE POINT & Pearson Correlation & $-.877^{* *}$ & 1 \\
AVERAGE & Sig. (2-tailed) & .002 & \\
& $\mathrm{~N}$ & 9 & 9 \\
\hline
\end{tabular}

**. Correlation is significant at the 0.01 level ( 2 tailed)

Based on the table correlation coefficient of moderate achiever students above, it showed that the significant correlation between emotional intelligence and English achievement of the moderate achiever of the fifth semester students of English literature department of UIN Alauddin Makassar was 0.002. Therefore, it indicated that there was significant correlation between the students' emotional intelligence and their English achievement because the significant correlation was at 0.01 level. In relation to the high achiever, the moderate achiever students' emotional intelligence also contributed to their English achievement. The students with a moderate level of Emotional intelligence also had a moderate level of GPA. It indicated that the students' emotional intelligence influences their outcome in learning English.

Table 5. Low Achiever Students

\begin{tabular}{cccc}
\hline No & Students & EI Score & GPA \\
\hline 1 & DV & 197 & 3.00 \\
2 & MZ & 162 & 3.00 \\
3 & AL & 170 & 2.98 \\
\hline
\end{tabular}

Based on the table 5 above, it showed that referring to the students' GPA, there were 3 students categorized as low achiever students. The highest score of the student's GPA was 3.00 and the lowest score was 2.98. While for the EI score, the highest was 197 and the lowest was 162

Table 6. Pearson Correlation Coefficient between Emotional Intelligence and English Achievement of Low Achiever Students

\begin{tabular}{llrr}
\hline & & EMOTIONAL & GRADE POINT \\
& & INTELLIGENCE & AVERAGE \\
\hline EMOTIONAL & Pearson Correlation & 1 & .299 \\
INTELLIGENCE & Sig. (2-tailed) & 3 & .807 \\
& $\mathrm{~N}$ & .299 & 3 \\
\hline GRADE POINT & Pearson Correlation & .807 & 1 \\
AVERAGE & Sig. (2-tailed) & 3 & 3 \\
& $\mathrm{~N}$ & & \\
\hline
\end{tabular}

Based on the table correlation coefficient of low achiever students above, it showed that the correlation between emotional intelligence and English achievement of the low achiever of the fifth semester students of English literature department of UIN Alauddin Makassar was 0.807. Therefore, it indicated that the correlation between the two variables was not significant because the correlation was significant at the level of 0.05 . The students' emotional intelligence of the low achiever did not contribute much to their English achievement. In relation to the table 5 above, it also showed that the student (DV) with good emotional intelligence score (197) had low English 
achievement (3.00). Thus, this showed that having good enough of emotional intelligence does not always make the student be a high or moderate achiever in learning English. The grade given by the lecturers could be influenced by many other factors, one of them is the students' emotional intelligence.

\section{Students' Learning and Engagement in English}

After conducting observation which referred to the students' categories (high, moderate, and low achiever), the researcher found out how each of the students' categories learnt and engaged in English. Here are the following descriptions:

Table 7. High achiever students

\begin{tabular}{|c|c|c|c|}
\hline NO & Student & GPA & English Learning Engagement \\
\hline 1 & $\mathrm{DN}$ & 4.00 & $\begin{array}{c}\text { Active (speaking and writing), } \\
\text { independent, confident, high motivated }\end{array}$ \\
\hline 2 & NS & 4.00 & $\begin{array}{l}\text { Active (speaking), independent, high } \\
\text { motivated,confident, empathetic }\end{array}$ \\
\hline 3 & $\mathrm{OC}$ & 4.00 & $\begin{array}{l}\text { Active (speaking), dependent, high } \\
\text { motivated, confident }\end{array}$ \\
\hline 4 & FB & 3.91 & $\begin{array}{l}\text { Active (speaking and writing), } \\
\text { independent, high motivated, } \\
\text { confident. }\end{array}$ \\
\hline 5 & MR & 3.82 & $\begin{array}{l}\text { Active (writing), independent, high } \\
\text { motivated, confident }\end{array}$ \\
\hline 6 & DL & 3.82 & $\begin{array}{l}\text { Active (speaking and writing), } \\
\text { dependent, high motivated, confident, } \\
\text { empathetic, }\end{array}$ \\
\hline 7 & $\mathrm{AD}$ & 3.82 & $\begin{array}{l}\text { Active (writing), independent, } \\
\text { motivated, confident, empathetic }\end{array}$ \\
\hline 8 & $\mathrm{AG}$ & 3.78 & $\begin{array}{l}\text { Active (writing), dependent, motivated, } \\
\text { confident }\end{array}$ \\
\hline 9 & SD & 3.73 & $\begin{array}{l}\text { Active (speaking and writing), } \\
\text { independent, high motivated, confident }\end{array}$ \\
\hline 10 & DS & 3.73 & $\begin{array}{l}\text { Active (writing), dependent, } \\
\text { empathetic, motivated, confident }\end{array}$ \\
\hline 11 & HS & 3.67 & $\begin{array}{l}\text { Active (speaking), dependent, high } \\
\text { motivated, confident }\end{array}$ \\
\hline 12 & IP & 3.64 & $\begin{array}{l}\text { Active (writing and speaking), } \\
\text { independent, motivated, confident }\end{array}$ \\
\hline 13 & WW & 3.64 & $\begin{array}{l}\text { Active (speaking), dependent, } \\
\text { motivated, confident }\end{array}$ \\
\hline
\end{tabular}

Table 7 above showed that there were 13 students categorized as high achiever students based on their GPA. Referring to the observation conducted by the researcher, those 13 high achiever students were all active English learners. There were 5 students (DN, FB, DL, SD, IP) who 
were active both in speaking and writing activity. They felt that speaking English was enjoyable as well as writing English. What they wrote should be be spoken and so should what they wrote. Thus, what they had learnt, it must have been practiced in their daily life without much worry about the mistakes. They don't let any small worries discourage them from pursuing their ultimate goals. In addition, the students were also high motivated learners. They tried to be top 10 in every semester and they were optimistic and confident with their ability. Besides that, those students were mostly independent learners. They learnt English even though the lecturer was not in the classroom. They learnt more from media and did not rely only on the lecturers. Whereas, spending much time learning English independently made them less empathetic to their friends. they were not the good listeners to share. They preferred to study individually than in a group.

While there were 4 students (NS, OC, HS, and WW) active more in speaking activity, like group discussion and presentation. They felt that writing English was more difficult than speaking one. There were a lot of rules to be learnt and had to be applied in writing. Therefore, they participated less in writing activity. Most of them were dependent English learners. Studying in group was their choice because it made them easier to share one another. Studying and interacting more in groups made them more empathetic to their friends. They assisted one another. They tended to finish their assignment by asking to the others.

In contrast, there were 4 students (MR, AG, AD, and DS) who were active mostly in written activity. They felt that writing was much easier than speaking English. They did not have to pronounce every single word correctly so they were less confident to produce spoken English. Those students were also mostly dependent English learners. They often needed others to share in learning English.

Table 8: Moderate Achiever Students

\begin{tabular}{|c|c|c|c|}
\hline NO & Student & GPA & English Learning Engagement \\
\hline 1 & RH & 3.45 & $\begin{array}{l}\text { Active (writing), dependent, } \\
\text { motivated, less confident, empathetic }\end{array}$ \\
\hline 2 & IR & 3.45 & $\begin{array}{l}\text { Active (writing), dependent, } \\
\text { motivated, less confident, empathetic }\end{array}$ \\
\hline 3 & NR & 3.45 & $\begin{array}{l}\text { Active (writing), dependent, } \\
\text { motivated, less confident, empathetic }\end{array}$ \\
\hline 4 & IS & 3.44 & $\begin{array}{l}\text { Active (writing), dependent, } \\
\text { motivated, less confident, empathetic }\end{array}$ \\
\hline 5 & $\mathrm{HN}$ & 3.36 & $\begin{array}{l}\text { Active (speaking), dependent, } \\
\text { motivated, less confident, empathetic }\end{array}$ \\
\hline 6 & NF & 3.36 & $\begin{array}{l}\text { Active (writing), dependent, } \\
\text { motivated, less confident, empathetic }\end{array}$ \\
\hline 7 & $\mathrm{RD}$ & 3.36 & $\begin{array}{l}\text { Active (writing), dependent, } \\
\text { motivated, less confident, empathetic }\end{array}$ \\
\hline
\end{tabular}

Table 8 showed that there were 7 students categorized as moderate English achievers. All were active more only in one skill. Most of them participated more in writing activity. Moreover, all the students were dependent learners. They were quite difficult to learn English individually. They needed whether lecturers or friends to assist them. However, they were motivated students. They had enough motivation to learn English more, whereas in the process of practice, they were less confident to produce the English particularly spoken English. So their self- confidence in speaking English should be presented.

Table 9: Low achiever students. 


\begin{tabular}{|c|c|c|c|}
\hline NO & Student & GPA & English Learning Engagement \\
\hline 1 & MZ & 3.00 & $\begin{array}{c}\text { Dependent, less motivated, less } \\
\text { confident }\end{array}$ \\
\hline 2 & DV & 3.00 & Dependent, motivated, less confident \\
\hline 3 & $\mathrm{AF}$ & 3.00 & $\begin{array}{c}\text { Dependent, less motivated, less } \\
\text { confident }\end{array}$ \\
\hline
\end{tabular}

Table 9 showed that there were only 3 students categorized as low achievers. They got the lowest GPA among their friends. They were dependent and less interested in learning English. They preferred to be silent in the classroom activity. Consequently, they came to class with less participation. Some of the English material did not make sense to them.

\section{High achiever students}

Interviewer: What do you think about learning English?

Student: In my mind, learning English is interesting and challenging. Being able to speak English is something great for me. So English not only about the theory but also more about how to practice the language. But for me, I like studying English. It makes me motivated.

Interviewer: How do you like studying English?

Student: It started by my hobby that was watching romantic western movies and I did not know the meaning. It made me curious, so after graduating from senior high school I decided to take an English major and until now I learn English from many sources.

Interviewer: Do you have target in learning English:

Student: Yes of course, I have. I expect I can continue my study in abroad.

Interviewer: So, how do you make it come true?

Student: Of course by keep studying, not only from the lecturers but also from many things.

In relation to the interview data above, the student as the representative of high achiever English learners. Based on the responses of student about her interest in learning English which started from her hobby to watch western movie without uderstanding the meaning and it made her curious so she decided to take English major, the researcher analyzed that having the curiousity to know more about English by deciding to take English major, it indicates that the student had managed her curiousity in a good way and it is one of the signs of a person having a good emotional intelligence as Travis Brad Berry stated in his article. Being curious about English also motivated her in learning English more. Both the high achiever students had target in learning English. They had something to achieve. Having target to go abroad and to be an interpreter made them more motivated to learn English. Having motivation is one of the emotional intelligence components described by Goleman. It demonstrates the ability to stay focused on the goal rather than backward. The students who display this skill are able to set their own goals and work to achieve those goals. In addition, both the students were independent learners. They studied English not only from the lecturers but also from other sources. They relied not only to the material given by the lecturers but also from their surroundings. Besides that both the students had good self-awareness and selfregulation in learning English. They know what they are good at and what they are terrible at. They realized that learning English is not an easy thing but as long as they kept trying, their English will be better.

\section{Moderate achiever student}

Interviewer: What do you think of learning English? 
Student: I think it is chalengging but sometimes the lecturers do not give more explanantion, so it depends on the lecturer also.

Interviewer: So, how do you handle the problem?

Student: I always ask my friends who understand more.

Interviewer: Why do you not ask the lecturer for more explanation?

Student: Sometimes I am afraid of asking directly to the lecturers. I feel nervous and I make errors.

Interviewer: Do you have target in learning English?

Student: Yes, I hope that I can be an English teacher. That is my idea .

While for the moderate achiever above, the researcher analyzed based on the responses that the student had enough motivation to learn English. It was showed by her idea to be an English teacher although it was still up and down. Asking her friends who understand more about the unclear material is a way of her to handle her weaknesses but being afraid of asking directly to the lecturer showed that student still less in self-regulation skill. Therefore, she needed to be controlled countinuedly.

\section{Low achiever student}

Interviewer: What do you think of learning English?

Student: I think it is complicated. English has many rules to be learnt.

Interviewer: How do you handle the situation?

Student: Just ask my close friend, but if they do not know I just keep silent.

Interviewer: Why do you not ask to your lecturer for more explanation?

Student: I am afraid and shy to the lecturer. My English is not good.

Interviewer: Do you have target in learning English?

Student: No, I just learn as my major.

For the low achiever student above, referring to her responses, the researcher analyzed that the student was less motivated in learning English. Believing that learning English is complicated learn made her uninterested in knowing English more. She does not have any targets in learning English. Having less motivation is her main problem. Therefore, any kinds of teaching method should be given to her to grow her motivation to learn English.

Based on the explanation gained both from observation and inteview, the researcher summarized that the high, moderate, and low achiever students were different in learning and engaging in English. The following table describes the differences:

Table 10. different in learning and engaging in English.

\begin{tabular}{cl}
\hline Students' Categories & \multicolumn{1}{c}{ Learning and Engagement in English } \\
\hline High Achiever & $\begin{array}{l}\text { Active, independent, motivated, confident, less } \\
\text { empathetic } \\
\text { Active, dependent, motivated, less confident, } \\
\text { Moderate Achiever }\end{array}$ \\
Low Achiever & $\begin{array}{l}\text { Less active, dependent, less motivated, less } \\
\text { confident }\end{array}$ \\
\hline
\end{tabular}

\section{Conclusions}

Based on the research findings and discussion above, the researcher concluded that there was significant correlation between emotional intelligence and English achievement of both the 
high and moderate achiever of the fifth semester students of English literature department of UIN Alauddin Makassar. While for the low achiever there was no. Some components of Emotional Intelligence could contribute more to the students' English achievement (self-awareness, selfregulation, and motivation) but some others contribute less (empathy and social skill). Besides that the high, moderate, and low achiever of the 2015/2016 fifth semester students of English literature department of UIN Alauddin Makassar were different in learning and engaging in English.

\section{References}

Abraham, R. (1999). Emotional Intelligence in Organizations: A Conceptualization. Genetic, Social \& General Psychology Monographs, 125(2), 209-225.

Alavinia, P., \& Kurosh, S. 2012. On the Would-be Bonds between Emotional Intelligence and Self-efficacy: The Case of Iranian EFL University

Bar-On, R. 1997b. Bar-On Emotional Quotient Inventory (EQ-i): Technical manual. Toronto, Canada: Multi-Health Systems.

Carmeli, A.2003. The Relationship between Emotional Intelligence and Work Attitudes, Behaviors and Outcomes, Journal of Managerial Psychology, 18, 788-813.

Ciarrochi, J., and J. Mayer. 2007. Applying Emotional Intelligence: A Practitioner's Guide. New York: Psychology Press/Taylor \& Francis

Goleman, D. 2004.What Makes a Leader? Harvard Business Review, 1-10.

Goleman, D. 1995. Emotional Intelligence. New York: Bantam Books

Goleman, D. 2003. Working with Emotional Intelligence, alih bahasa oleh Alex Tri Kantono Widodo. Jakarta: Gramedia Pustaka Utama.

Jalil. 2014. Investigating The Relationship between Emotional Intelligence and Language Achievement: A Case of TEFL and Non-TEFL University Students. International Journal of Language Learning and Applied Linguistics World, Volume 5 (3).

Rukmini. 2012. Emotional Intelligence among College Students. International Journal of Research in Commerce, IT \& Management;2012, Vol. 2 Issue 4, p106

Salovey, P. 2004. Keys to Educational Psychology: Emotion and Emotional Intelligence for Educators. ELT Journal p.31.

Singh., et al. 2009. The Influence of Emotional Intelligence and Learning Style on Students' Academic Achievement. A Thesis. Faculty of Administrative Science and Policies Studies: MARA Technological University of Sarawak.

Strongman, K. T. 2003. The Psychology of Emotion, Fifth Edition. Department of Psychology, University of Canterbury Christchurch, New Zealand. 
Journal of Applied Linguistics (JoAL), Vol. 1 No. 2, January 2022. e-ISSN 2809-1922, p-ISSN 2809-1914

Vela, R. H. 2003. The Role of Emotional Intelligence in the Academic Achievement of First Year College Students. A Dissertation. Texas A\&M University Kingsville and Texas A\&M University-Corpus Christi.

Published by English Lecturers and Teachers Association (ELTA)

Copyright (C) 2022, authors 